\title{
The Effect of the E-Patuh Application on HIV/Aids Patients' Adherence in Consuming Antiretroviral
}

\author{
Alfian, Kusman Ibrahim, Imas Rafiyah \\ Faculty of Nursing Universitas Padjadjaran, Bandung, Indonesia \\ Corresponding Email: alfianthyan@gmail.com
}

Submitted: 29-06-2018 Accepted: 10-04-2019 Published: 28-04-2019

\begin{abstract}
Adherence to medication is a behavior that refers to the client's obedience to following treatment, and making lifestyle changes in accordance with the recommendations from health care providers. Antiretroviral adherence is of utmost importance for HIV / AIDS patients. Its effects are often a problem in antiretroviral treatment and toxicity and are often a reason for switching or stopping antiretroviral treatment. This study aims to determine the effect of the 'E-Patuh' application on antiretroviral adherence in HIV / AIDS patients in West Java. The research design was quasi-experimental with a nonequivalent control group design. The locations of this research were in RSUD Kota Bandung and in RSUD Kota Banjar. Respondents were selected without randomization and used a purposive sampling technique. Respondents in this study were 30 people. The data were obtained using self-report questionnaires. The intervention group was monitored for 30 days with the android-based 'E-Patuh' application and monitored on the 'E-Patuh' website and then measured the value of adherence with self-reports. Data were analyzed using SPSS 22 with chi-square test. The results showed that there was a significant difference between the value of adherence before and after the application of 'E-Patuh' in the intervention group $(\mathrm{p}<0.05)$ with a value of $p=0.006$. The results of this study prove that the use of the 'E-Patuh' application has a positive effect on adherence to ARV medication in the intervention group with the 'E-Patuh' application support system. The use of 'E-Patuh' is very helpful in improving ARV adherence in HIV / AIDS patients. The features contained in 'E-Patuh' are directly reminiscent of the time to take medication for PWLH. 'E-Patuh' should be a consideration for PLHIV and health care providers in hospitals to improve ARV adherence to reduce mortality in people living with HIV.
\end{abstract}

Keywords: Adherence, Antiretroviral, E-Patuh Applications. 
Alfian: The Effect of the E-patuh application on HIV/AIDS Patients Adherence in Consuming Antiretroviral

\section{Introduction}

Human Immunodeficiency Virus (HIV) is a virus that attacks leukocyte (lymphocytes) in human body and causing acquired immune deficiency syndrome (AIDS) (Kemenkes, 2014). HIV/AIDS is a complex chronic disease. The number of HIV in Indonesia in the fourth quarter of 2017 was 14,640 and AIDS was 4,725 people. The highest AIDS percentage at 30-39 years $(35.2 \%)$, followed by 20-29 years your (29.5\%) and 40-49 years $(17.7 \%)$. West Java is the third highest number of HIV infections in Indonesia in the period of March 2016 amounted to 28,964 people and the number of AIDS in West Java was ranked sixth in Indonesia with 6,502 people.

The development of using antiretroviral therapy as a treatment of choice in HIV/ AIDS has significantly improved the health condition of HIV people. Palella et al. (1998) explains that ARVs have illustrated that HIV/AIDS patients can be treated, to reduce the morbidity, mortality and improve quality of life. Hypersensitivity reactions to antiretroviral drugs are more common in HIV patients than in other general disease populations. The reasons why people with HIV experience hypersensitivity reactions to antiretroviral medications are more often multi-factor, such as immune hyperactivity factors, changes in medication metabolism, profilesocytes, oxidative stress, and genetic predisposition (Nursalam, 2007).

The medication effects should not be an obstacle to starting antiretroviral therapy. Not all patients have effects of arising from the ARV treatment. ARV treatment is beneficial when compared to the risk of morbidity and death that would occur if the patient did not get ARV therapy (Kemenkes, 2011).

The level of antiretroviral adherence in Indonesia is low, with a range of $40-70 \%$ still below the national target of adherence $>95 \%$ (Latif, Maria, \& Syafar, 2014). Kemenkes (2017) showed the number of people living with HIV who were getting ARVs in the fourth quarter of 2017 was 91,369 people. The total of 88,386 people used first-line regimens, 2,983 people receiving second line and 2,983 people was drop out of medication.

Cohen et al. (2011) said Disobedience in the treatment of antiretroviral medication has a significant impact on patients who live it, such as the onset of symptoms that aggravate the state of the patient. Technology developments on ARV adherence interventions have been used in PLHIV including of pager, smartphone, SMS, video, computer-based programs and the development of behavioral intervention technology intervention technology (BITs) to improve ARV compliance (Pellowski \& Kalichman 2012). Along with the development of existing interventions, nurses should play a role to increase ARVs adherence. Dayer et al. (2013) and Whellan et al. (2013) explained that their study focus on improving to ARVs adherence, providing educational information on ARV medication treatment and HIV/AIDS information based on electronic monitoring system.

In this study The E-Patuh application is developed from the existing electronic monitoring system applications based on Android and website system with Google servers to store patient's data. The features are improving of medication adherence and document medical history, CD4 history, and symptoms experienced by PLWHA during medication treatment. The forms of the report are immediately sent and documented in the "E-Patuh" website application system. E-Patuh Supported with reminders and notifications to remind people living with HIV to take medication on time.

\section{Method}

This study used quasi experimental with nonequivalent control group design approach with experimental group (A) and control group (B). The value of ARV medication adherence was measured in pretest and posttest. The experimental group was given intervention by using E-Patuh android application as user and then readied for respondent's smartphone. The Experimental group was conducted in Ujung Berung Hospital. For the control group were not given intervention in the form of E-Patuh android application and was conducted in Banjar Hospital. This study would evaluate the treatment of E-Patuh in a month. 
Alfian: The Effect of the E-patuh application on HIV/AIDS Patients Adherence in Consuming Antiretroviral

The sample technique in this research used nonprobability sampling with purposive sampling. The numbers of experimental group were 15 respondents and 15 respondents for control group without any randomization in each group. The data were tested statistically to determine the difference of scores in the intervention group and control group on pretest and post-test using chi square test of SPSS program to measure the pairs of nominal data or dichotomy (Dahlan, 2015).

This study used indirect measurement methods in the form of self-report using the Morisky Medication Adherence Scale (MMAS) questionnaire. Measurement of ARV medication adherence used the selfreport questionnaire was developed with a four-item scale of questions and supplemented with additional items that discussed the circumstances surrounding compliance behavior. The questions were measured by 4 items, namely 1 . Are you sometimes having difficulty remembering the time to take medicine?, 2. When you feel good, do you sometimes stop taking medicine?, 3. Think four days back, have you missed it Taking medicine?, 4. At times when your condition feels worse, do you stop taking medicine? The question category was responded to yes/ no for each item with a response dichotomy (Morisky, Ang, Krousel-Wood, \& Ward, 2008).

\section{Result}

Table 1 The Respondent's Characteristics

\begin{tabular}{|c|c|c|c|c|c|}
\hline \multirow[t]{3}{*}{ Characteristic } & \multicolumn{4}{|c|}{ Group } & \multirow[t]{3}{*}{$\mathbf{p}$} \\
\hline & \multicolumn{2}{|c|}{ Intervention } & \multicolumn{2}{|c|}{ Control } & \\
\hline & f & $\%$ & f & $\%$ & \\
\hline Age (Old): & & & & & 0.247 \\
\hline $17-20$ years & 6 & 40 & 3 & 20 & \\
\hline 21-40 years & 5 & 33.3 & 8 & 53.3 & \\
\hline 40-60 years & 4 & 26.7 & 4 & 26.7 & \\
\hline Gender: & & & & & 0.000 \\
\hline Male & 14 & 93.3 & 7 & 46.7 & \\
\hline Female & 1 & 6.7 & 8 & 53.3 & \\
\hline Married Status: & & & & & 0.161 \\
\hline Married & 3 & 20 & 6 & 40 & \\
\hline Single & 10 & 66.7 & 7 & 46.7 & \\
\hline Divorce & 2 & 13.3 & 2 & 13.3 & \\
\hline Education: & & & & & 0.638 \\
\hline Elementary & 1 & 6.7 & - & - & \\
\hline Middle & 3 & 20 & 3 & 20 & \\
\hline High & 9 & 60 & 6 & 40 & \\
\hline University & 2 & 13.3 & 6 & 40 & \\
\hline Work: & & & & & 0.593 \\
\hline Private employees & 7 & 46.7 & 9 & 60 & \\
\hline Entrepreneurship & 3 & 20 & 1 & 6.7 & \\
\hline Unemployment & 3 & 20 & 1 & 6.7 & \\
\hline Laborer & 1 & 6.7 & 1 & 6.7 & \\
\hline IRT & 1 & 6.7 & 3 & 20 & \\
\hline Duration of ARVs: & & & & & 0.091 \\
\hline 15 years & 10 & 66.7 & 3 & 20 & \\
\hline
\end{tabular}

Volume 7 Issue 1 Apr 2019 
Alfian: The Effect of the E-patuh application on HIV/AIDS Patients Adherence in Consuming Antiretroviral

$6-12$ months

5 - 10 years

Type of ARV

3FDC

Lamipudin, Tenopovir, Evafiren

Duviral dan evafiren

Lamifudin, neviral, TDF

Duviral dan neviral

Side Effects of Treatment:

No complaints

Nausea

Dizziness, nausea

Rash

Dizzy and limp

$p<0.005$ (homogeneity test) $\begin{array}{llll}5 & 33.3 & 6 & 40\end{array}$

$\begin{array}{llll}- & - & 6 & 40\end{array}$

$\begin{array}{llll}10 & 66.7 & 11 & 73.3\end{array}$

$\begin{array}{ll}1 & 6.7\end{array}$

$2 \quad 13.3$

$1 \quad 6.7$

$5 \quad 33.3$

0.521

Table 2 Pretest Score the ARV adherence in Intervention and Control Group

\begin{tabular}{|c|c|c|c|c|c|}
\hline \multirow[t]{3}{*}{ Group } & \multicolumn{3}{|c|}{ Adherence Level } & \multirow[t]{3}{*}{$\mathbf{x}^{2}$} & \multirow[t]{3}{*}{$\mathbf{p}$} \\
\hline & High & Medium & Low & & \\
\hline & $\mathbf{f}(\%)$ & $f(\%)$ & $\mathbf{f}(\%)$ & & \\
\hline Pre- test intervention group & $6(40.0)$ & $5(33.5)$ & $4(26.5)$ & 2.812 & $0.245^{*}$ \\
\hline Pre-test control group & $12(80.0)$ & $3(20.0)$ & - & & \\
\hline
\end{tabular}

Table 3 Posttest Score the ARV adherence in Intervention and Control Group $(\mathbf{n}=\mathbf{3 0})$

\begin{tabular}{lccccc}
\hline \multirow{2}{*}{ Group } & \multicolumn{3}{c}{ Adherence Level } & \multirow{2}{*}{$\mathbf{x}^{\mathbf{2}}$} & p \\
\cline { 2 - 5 } & High & Medium & Low & & \\
\cline { 2 - 5 } & $\mathbf{f ( \% )}$ & $\mathbf{f ( \% )}$ & $\mathbf{f ( \% )}$ & & \\
\hline Pre- test intervention group & $8(53.3)$ & $7(46.7)$ & - & $0.013 *$ \\
\hline Pre-test control group & $11(73.3)$ & $4(26.7)$ & - & \\
\hline chi square test $p<0.05$ & & & \\
\hline
\end{tabular}

Table 4 Pretest and Posttest Score an ARV Adherence in Intervention Group $(\mathbf{n}=15)$

\begin{tabular}{|c|c|c|c|c|c|}
\hline \multirow[t]{3}{*}{ Group } & \multicolumn{3}{|c|}{ Adherence Level } & \multirow[t]{3}{*}{$\mathbf{x}^{2}$} & \multirow[t]{3}{*}{$\mathbf{p}$} \\
\hline & High & Medium & Low & & \\
\hline & f $(\%)$ & f $(\%)$ & f $(\%)$ & & \\
\hline Pre- test intervention group & $6(40.0)$ & $5(33.5)$ & $4(26.5)$ & 10.179 & 0.006 \\
\hline Pre-test control group & $8(53.3)$ & $7(46.7)$ & - & & \\
\hline
\end{tabular}

Table 5 Pretest and Postest Score an ARV adherence in Control Group $(n=15)$

\begin{tabular}{|c|c|c|c|c|c|}
\hline \multirow[t]{3}{*}{ Group } & \multicolumn{3}{|c|}{ Adherence Level } & \multirow[t]{3}{*}{$\mathbf{x}^{2}$} & \multirow[t]{3}{*}{$\mathbf{p}$} \\
\hline & High & Medium & Low & & \\
\hline & f $(\%)$ & $\mathbf{f}(\%)$ & f $(\%)$ & & \\
\hline Pre- test intervention group & $12(80.0)$ & $3(20)$ & - & 3.068 & 0.080 \\
\hline Pre-test control group & $11(73.3)$ & $4(26.7)$ & - & & \\
\hline
\end{tabular}


Alfian: The Effect of the E-patuh application on HIV/AIDS Patients Adherence in Consuming Antiretroviral

The table 1 describes the characteristics of respondents between the intervention and control groups. The study showed the most respondents were range of aged 21-40 years $(53.3 \%)$ and almost all respondents in the intervention group were male $(93.3 \%)$. The marital status data most of the respondents were single on intervention group $66.7 \%$ and $46.7 \%$ for control group. Most of the respondent was senior high school with 9 people $(60 \%)$, private employment amounted to 9 people $(60 \%)$. Most of the respondents suffered from HIV-positive people and underwent ARVs within 1-5 years at 10 $(60.7 \%)$ in the intervention group. Most of the 3FDC ARVs consumed by all respondents were 21 respondents. 1 person $(6.7 \%)$ of the control group did not have antiretroviral side effects but in the intervention group. a small percentage of $1(6.7 \%)$ of the respondents had side-effect rash on the skin.

Pretest intervention and control group using chi square test showed on the table 3 and the result obtained $\mathrm{p}$ value $=0.245$. Since $p$ value 0.05 hence statistically there is no significant difference of pretest score of ARV adherence medication level between group intervention and control groups. Pretest adherence levels in the control arm were almost $12(80 \%)$ in high adherence. Meanwhile, in the intervention group there are still respondents with compliance of less $4(26.5 \%)$ of respondents.

Posttest in intervention and control group using chi square test on table 3 obtained $p$ value $=0.013$, because $\mathrm{p}$ value $<0.05$ then statistically there was significant difference in post test score of adherence medication intervention group antiretroviral drug and control groups. The post-test adherence level in the control group of $11(73.3 \%)$ was in high adherence level and the intervention group had respondents with high adherence of $8(53.3 \%)$ respondents.

In the test to know the difference of pretest and posttest in intervention and control group using categorical comparative analysis not paired by using chi square. Differences of ARV preoperative and posttest test compliance scores in the intervention group will be presented in table and the control group will be presented in table below:
Between pre-test in intervention group got small part of adherence value $4(26 \%)$ of respondent with low compliance category at pre-test and at post-test there is no value of compliance of respondent in low adherence category. The result of statistic test with chi square test in table was obtained $p$ value $=0.006$, because $p$ value $<0.05$ then statistically there is a significant difference between antiretroviral drug adherence level score before and after giving of E-Patuh application in intervention group.

In the test of difference between pretest and posttest in control group using chi square test in table 5 obtained $\mathrm{p}$ value $=0.080$, because $p$ value $<0.05$ hence statistically there is no significant difference between antiretroviral medication adherence level scores in group control before and after application of E-Patuh to the intervention group.

\section{Discussion}

This study prove a positive effect of E-Patuh applications against ARV medication adherence on the intervention group. The features provide reminder of taking the medicine for respondents in real time, enlarge the knowledge's, to guide the patient for health care provider in West Java and changes the patient behavior in ARV medication.

Several methods have been developed to improve ARV adherence by building up the android and website monitoring system. Study of Dayer's et al. (2013) shows the methods of changing patient behavior using reminders, counseling, strengthening, education, simplifying the dosage, or combining those methods. In general, the compliance interventions are categorized as behavioral, educational, or organizational based on modifying the environment or patient, delivering information, or reducing the risks that impede treatment and establish communication with health care providers.

A similar study Zia's (2014) on the implementation of ARV antiretroviral monitoring system by smartphone-based client server method shows three respondents stated strongly agree that the reminder helps to remind ARV medication. The respondent agree that the message feature can facilitate 
Alfian: The Effect of the E-patuh application on HIV/AIDS Patients Adherence in Consuming Antiretroviral

for communicating with the clinic staff while on ARV therapy, to help the officer in the process of collecting the results of CD4 examination, determines the consumption schedule and facilitates communication between the officer and the patient during the ARV therapy. Dayer's et al. (2013) again illustrates the potential benefits of smartphone technology to increase effectiveness in compliance programs, refine financing, as a real-time tool for evaluating medication adherence.

The study of electronic monitoring system became good opportunity in the modernizing of information and telecommunication tools in health community. The expansion of information and technology should be in line with utilization in the field of health specially in monitoring the system for ARV medication adherence to patients who living with HIV.

After giving for a month of E-Patuh application to the intervention group on 15 respondents and remain active using E-Patuh application the respondent still get the medication adherence intervention in the form of reminder with alarm and notification time of taking the medicine on time. While using the E-Patuh application researchers have submitted articles on HIV/AIDS to be able to provide information and education about the importance of medication adherence and educate the respondents' understanding of HIV/AIDS.

After using E-Patuh during the treatment package program, it was found that 5 respondents still had difficulty remembering the time to take medication but on the other hand there were increasing of adherence to 6 respondents who before using E-Patuh had trouble often skipping medication within four days. This compliance improvement is evidenced by no respondents claiming to have a problem with taking time to take medication time during the use of E-Patuh.

The E-Patuh application is an androidbased smartphone app and website that is connected with internet network that can access communication, information and as remainder. This technology provides the principle of benefit to PLWHA to improve the behavior of obedient to ARV. The features contained in the E-Patuh application can enhance compliance by providing remainder or alarm to take medication so that they can directly change their behavior by providing health promotion through APP, providing information on medication schedule, education delivery, and health service information. All information and education provided can be known by the notification that goes into android system of PLWHA.

The descriptive result indicates the level of adherence to taking antiretroviral drugs before and after the administration of the E-Patuh Application in the control group. From the table shows almost all the respondents have high adherence with the amount of $12(80 \%)$ in the control group pre-test. After the provision of E-Patuh application in the intervention group showed that there was a decrease in compliance rate of PLHIV as evidenced by the compliance level in the control group with the high adherence category amounted to $11(73.4 \%)$. The level of education in the control group was partially educated at university level with $6(40 \%)$ respondents and SMA $6(40 \%)$ respondents. The level of education in the control group tends to be better so it has better pre-test and post-test compliance percentage.

The effects of antiretroviral treatment in the control group were mostly 8 (53.3\%) respondents felt nauseated. As a result of side effects of ARV treatment one of the factors that inhibited adherence to the control group said 2 respondents discontinued treatment when physically felt better. This research is supported by research of Sugiharti, Yuniar, and Lestary (2014) which get nausea, fever, rash made ODHA cannot stand side effect so decided to stop treatment.

Marital status in the control group married one of the social support factors to the support system of respondents in ARV adherence with $6(40 \%)$ of respondents. In line with Galistiani and Lia (2013) say social support especially in the context of intimate relationships or the quality of marriage and family relationships is the most important source of social support. Social support from people around the patient can be a boost to HIV treatment adherence.

In this study, the extent of ARV adherence in general is quieted $<95 \%$ below the national target. It will have an impact on the spread or suppression of HIV virus to PLHIV. With the 
Alfian: The Effect of the E-patuh application on HIV/AIDS Patients Adherence in Consuming Antiretroviral

issue, WHO and the Ministry of Health through a system of curing with this prevention, care and treatment program emphasize that ongoing care and with attention to ARV adherence can suppress the virus in the body, reduce the risk of transmission to others, help people living with HIV and help keep long life (Kemenkes, 2017).

Given that antiretroviral therapy is a lifelong therapy, then the problem of treatment adherence was a common problem. Various studies show obstacles to obstacles such as fear of side effects, forgetfulness, unhealthy lifestyles, poor health conditions, missing medicine boxes, lack of personal awareness, opportunistic infections, daily activities, economic problems insufficient income for ARV treatment, unemployment, and fear of stigma. While adherence supporters, among others, have a regular schedule of taking medication, understanding the importance of adherence, getting good treatment results and confidence in the treatment process (Yuniar, Handayani, \& Arsyastami, 2012).

Technological developments cannot be denied so quickly and rapidly in all aspects of human life. This becomes an opportunity and a challenge for us especially in the field of health. The demand of technological development with the internet network in the health world leads the health service system in paying attention to the compliance of antiretroviral programs for PLHIV. Utilization of technology in the field of health services in hospitals or in the community, especially for PLWHA will assist PLWHA in undergoing a life-long antiretroviral regimen program, facilitate access to health services, delivery of information and education, time efficient and financing in various aspects of service. Acceptance of technology based on android and website in it the use of E-Patuh application to PLWHA will guide some aspects of knowledge, attitude of PLWHA in antiretroviral treatment program so that ODHA become know, understand and able to change behavior in taking decision during undergoing ARV treatment program.

Taiwo and Downe (2013) said that in Technology Acceptance Models And Theories argue that interaction between humans and technology will affect the social and psychological factors of individuals and even individual characteristics. A similar opinion is supported by the theory of Acceptance Technology Model (TAM) by Davis (1989) is a model for predicting individual acceptance of a new technology. TAM is actually adopted from the theory of reasoned action model (TRA) by Ajzen and Fishbein (1975), the theory of action with one premise that reactions and perceptions of a person to something that will determine the attitude and behavior of the person.

Differences in adherence levels of PLHIV pretest and posttest in both groups tended to better control group. This can be influenced by some external and internal support factors in the patient so as to perceive and behave toward something that can improve compliance. External support factors are employment, most respondents work as private employees in the control group of $9(60 \%)$ of respondents and intervention groups $7(46.7 \%)$ with varying salary. A minority of $3(20 \%)$ of the respondents in the intervention group were unemployed so that the work factor could be a factor in the intervention group had less compliance than the control group because the work would affect income to meet the needs of antiretroviral treatment. Although ARV programs are free but access to ARVs requires financing. This study was supported by Wulandari (2015) study which stated that insufficient income made respondents did not routinely come to take the medicine, and vice versa respondents with middle to high income and work become private employees tend to always actively come to take antiretroviral drugs.

\section{Conclusion}

The growth of technology becomes good change for people living with HIV to be more effective in ARV medication program. PWLH needs the program for monitoring their ARV medication. The implementation E-Patuh based android and website system had positive outcome for increasing ARVs medication adherence.

After using E-Patuh during the treatment package program, it was found that 5 respondents still had difficulty remembering the time to take medication but on the other 
Alfian: The Effect of the E-patuh application on HIV/AIDS Patients Adherence in Consuming Antiretroviral

hand there were increasing of adherence to 6 respondents who before using E-Patuh had trouble often skipping medication within four days. This compliance improvement is evidenced by no respondents claiming to have a problem with taking time to take medication time during the use of E-Patuh. . The ARVs adherence medication score in control group were relatively better at the beginning. Although in the control group there were no less adherence categories for the respondents, but the control group experienced a decrease in adherence after posttest. There were 2 respondents who expressed difficulties remembering the time of taking the medicine and 1 respondent said sometimes stop treatment if feeling better. Patient compliance issues in this control group tend to be time-dependent and the prevalence is low in pre-test. Different when done post-test after obtained 2 respondents expressed difficulties remembering taking medicine and 2 respondents stated stop treatment if feeling better.

\section{References}

Ajzen, I. (1975). From intentions to actions: A theory of planned behavior. In: Kuhl, J., Beckman, J., Editors. Action-control: From cognition to behavior. Heidelberg: Springer. p. 11-39. 20 .

Cohen, M.S., Shaw, G.M., McMichael, A.J., \& Haynes, B.F. (2011). Acute HIV-1 Infection. New England Journal of Medicine, 364(20), 1943-1954. https://doi.org/10.1056/ NEJMra1011874.

Dahlan. (2014). Statistik untuk kedokteran dan kesehatan, deskriptif, bifariat, dan multifariat, dilengkapi aplikasi menggunakan SPSS (Edisi 6). (Statistics for Medicine and Health, Descriptive, Bivariate, and Multivariate, Complete with Applications Using SPSS). Jakarta: Salemba Medika.

Davis, Fred D. (1986). Technology Acceptance Model for Empirically Testing New End-User Information System Theory and Results."Dissertation. Massachusetts Institute of Technology (MIT).
Dayer, L., Heldenbrand, S., Anderson, P., Gubbins, P.O., \& Martin, B.C. (2013). Smartphone medication adherence apps: Potential benefits to patients and providers. J Am Pharm Assoc, 53(2), 172-181. https:// doi.org/10.1331/JAPhA.2013.12202. Smartphone.

Galistiani, G.F. \& Lia, M. (2013). Kepatuhan pengobatan antiretroviral pada pasien HIV/ AIDS di RSUD Prof. Dr. Margono Soekarjo Purwokerto. (Adherence of Antiretroviral Treatment in HIV / AIDS Patients in Prof. Rsud. Dr. Margono Soekarjo Purwokerto). Media Farmasi, 10(2), 94-103. Retrieved from Journal.Uad. Ac.Id/Index.Php/ MediaFarmasi/Article/Download/.../845 at August, 25, 2015.

Kemenkes RI. (2011). Pedoman tata laksana klinis infeksi HIV dan terapi antiretroviral pada orang dewasa. (Guidelines for Clinical Management of HIV Infection and Antiretroviral Therapy in Adults). Dirtjen Pengendalian Penyakit \& Penyehatan Lingkungan. Jakarta: Kemenkes RI.

Kemenkes RI. (2017). Kajian epidemologi HIV Indonesia 2016. (The 2016 Indonesian HIV Epidemiology Study). Direktorat Jendral Pencegahan dan Pengendalian Infeksi Kementrian Kesehatan Republik Indonesia. Jakarta: Kemenkes RI.

Latif, F., Maria, I.L., \& Syafar, M. (2014). Efek samping obat terhadap kepatuhan pengobatan antiretroviral orang dengan HIV/ AIDS. (Drug Side Effects on Adherence to Antiretroviral Medication for People with HIV / AIDS). Kesmas: National Public Health Journal, 9(2), 101. https://doi.org/10.21109/ kesmas.v9i2.495.

Morisky, D. E., Ang, A., Krousel-Wood, M., \& Ward, H. J. (2008). Predictive validity of a medication adherence measure in an outpatient setting. Journal of Clinical Hypertension, 10(5), 348-354. https://doi. org/10.1111/j.1751-7176.2008.07572.x.

Nursalam. (2007). Asuhan keperawatan pada pasien terinfeksi HIV/AIDS. (Nursing care for patients infected with HIV / AIDS). 
Alfian: The Effect of the E-patuh application on HIV/AIDS Patients Adherence in Consuming Antiretroviral

Jakarta: Salemba Medika.

Palella, F.J, Delaney, K.M, Moorman, A. C, Loveless, M.O., Fuhrer, J., Satten G.A., Aschman, D.J., Holmberg, S.D., ... et al. (1998). Declining morbidity and mortality among patients with advanced human immunodeficiency virus infection. HIV Outpatient Study Investigators. $N$ Engl $J$ Med. 26, 338(13), 853-60.

Pellowski, J., \& Kalichman, S. (2012). Recent advances in technology delivered interventions for people living with HIV. Current HIV/AIDS Reports, 9(4), 326-334.

Sugiharti, Yuniar, \& Lestary. (2014). Gambaran kepatuhan orang dengan HIVAIDS (ODHA) dalam minum obat ARV di Kota Bandung, Provinsi Jawa Barat, Tahun 2011-2012. (Description of Compliance of People with HIV-AIDS (PLHAs) in Taking Arv Drugs in Bandung City, West Java Province, 2011-2012).

Taiwo, A., \& Downe, A. (2013). The theory of user acceptance and use of technology (UTAUT): A meta-analytic review of empirical findings. Journal of Theoretical and Applied Information Technology, 49(1),
$48-58$.

Whellan,D.J.,Ellis, S.J.,\&Kraus, W.E.(2013). Real-time electronic adherence monitoring is feasible, comparable to unannounced pill counts, and acceptable. AIDS Behav. NIH Public Access, 151(6), 414-420. https://doi. org/10.1097/CCM.0b013e31823e986a.A.

Wulandari, Y. (2015). Hubungan karakteristik pasien dengan tingkat kepatuhan terapi ARV di Rawat Jalan Upi Rumah Sakit dr. Soetomo. (The Relationship between patients characteristics and the level of adherence to ARV therapy in Upi Outpaatient Hospital dr. Soetomo). Kesmas, 9(1). Maret 2015, pp. 1 6 ISSN: $1978-0575$.

Zia, U.W.P. (2014). Penerapan sistem monitoring terapi ARV (Antiretroviral) dengan metode client server berbasis smartphone pada RSUP Dr. Sarjito. (Application of the Arv Therapy Monitoring System (Antiretroviral) with the SmartphoneBased Client Server Method at Rsup Dr. Sarjito). Jurnal Sarjana Teknik Informatika, 2(1), 2338-5197. Retrieved from http:// journal.uad.ac.id/index.php/JSTIF/article/ viewFile/2628/2142. 